\title{
KEBIJAKAN KEUANGAN DAN SIKLUS PELAKSANAAN ANGGARAN BELANJA PEMERINTAH DAERAH UNTUK PENANGANAN PANDEMI COVID-19
}

\author{
Iklima Rahmadian Adi Wibowo ${ }^{1)}$; Iskandar ${ }^{2)}$ \\ 1) iklima.adiwibowo@gmail.com, Politeknik Keuangan Negara STAN* \\ 2) iskandar@pknstan.ac.id, Politeknik Keuangan Negara STAN \\ *email korespondensi
}

\begin{abstract}
The emergency conditions caused by the Covid-19 pandemic require the government to respond, both in terms of financial policy and its implementation quickly. This study aims to identify the application of financial policies in handling Covid-19 and to review the implementation cycle of the "ABC" Regency Regional Government budget for handling the Covid-19 pandemic. Data collection was carried out through literature study and field study methods in the form of interviews and observations in data collection at the "ABC" Regency Regional Finance Agency to then be processed and analyzed qualitatively with interactive methods. The results showed that the "ABC" District Government's financial policy towards the Covid-19 pandemic consisted of accelerating budget refocusing/reallocation, and rationalizing the revenue budget, as well as optimizing the use of unexpected expenditures that were budgeted centered on SKPKD. The series of activities carried out in the budget implementation cycle involve PPKD and activity and/or financial managers at SKPD related to Covid-19 handling. The stages in the cycle are almost the same as the non-Covid-19 spending process, but differ in terms of preparing the adjustment of implementation documents, and in accelerating the disbursement of funds. The results of the research can be a lesson in anticipating urgent/emergency situations.
\end{abstract}

Keywords: Expenditure Cycle, Unexpected Expenses, Regional Goverment Spending, Covid-19

\begin{abstract}
Abstrak
Kondisi darurat yang diakibatkan oleh pandemi Covid-19 menuntut perlunya respon pemerintah, baik aspek kebijakan keuangan maupun pelaksanaannya secara cepat. Penelitian ini bertujuan untuk mengidentifikasi penerapan kebijakan keuangan dalam penanganan Covid-19 dan melakukan tinjauan terhadap siklus pelaksanaan anggaran belanja Pemerintah Daerah Kabupaten "ABC" untuk penanganan pandemi Covid-19. Pengumpulan data dilakukan melalui studi kepustakaan dan metode studi lapangan berupa wawancara serta observasi dalam pengumpulan data pada Badan Keuangan Daerah Kabupaten "ABC" untuk kemudian diolah dan dianalisis secara kualitatif dengan metode interaktif. Hasil penelitian menunjukkan bahwa kebijakan keuangan Pemerintah Daerah Kabupaten "ABC" terhadap pandemi Covid-19 terdiri atas percepatan refocusing/realokasi anggaran, dan rasionalisasi anggaran pendapatan, serta optimalisasi penggunaan belanja tidak terduga yang dianggarkan terpusat pada SKPKD. Rangkaian aktivitas yang dilakukan dalam siklus pelaksanaan anggarannya melibatkan PPKD dan pengelola kegiatan dan/atau keuangan pada SKPD yang terkait dengan penangan Covid-19. Tahapan dalam siklus hampir sama dengan proses belanja non penanganan Covid-19, tetapi berbeda dalam hal penyiapan penyesuaian dokumen pelaksanaan, dan percepatan dalam pencairan dana. Hasil penelitian dapat menjadi pembelajaran dalam mengantisipasi keadaan yang mendesak/darurat.
\end{abstract}

Kata Kunci: Siklus Belanja, Belanja Tidak Terduga, Belanja Daerah, Covid-19

\section{PENDAHULUAN}

Pada hakikatnya, pemerintah memiliki kewajiban untuk meningkatkan kesejahteraan rakyatnya. Namun, kesejahteraan warga negara menjadi terancam sejak adanya pandemi akibat corona virus disease 2019 (Covid-19). Penyebaran virus ini telah ditetapkan sebagai bencana nasional melalui Keputusan Presiden No. 12 Tahun 2020. Oleh karena itu, pemerintah diharuskan untuk cermat dalam melakukan pengeluaran untuk penanganan pandemi Covid-19, mulai pencegahan penyebaran hingga dampak yang diakibatkan.

Kondisi darurat yang diakibatkan oleh pandemi Covid-19 memerlukan respon pemerintah untuk segera menghadapi situasi yang mendesak ini. Pemerintah segera menerbitkan Peraturan Pemerintah Pengganti Undang-Undang (Perpu) tentang Kebijakan Keuangan Negara dan Stabilitas Sistem Keuangan untuk Penanganan Pandemi Covid-19 dan/atau dalam Rangka Menghadapi Ancaman yang Membahayakan Perekonomian Nasional 


\section{JURNALKU}

Volume 1 No. 4, Desember 2021

dan/atau Stabilitas Sistem Keuangan, yang akhirnya ditetapkan menjadi Undang-Undang No. 2 Tahun 2020.

Respon pemerintah untuk penanganan pandemi, antara lain diterapkan melalui pendanaan tambahan, otorisasi transfer dana cadangan, dan pengurangan pengeluaran lintas lembaga (Joyce dan Prabowo, 2020). Kim (2020) menyebutkan bahwa diperlukan pula respon anggaran untuk pengeluaran publik dalam rangka memenuhi keperluan penanganan pandemi Covid-19. Respon anggaran pemerintah ini digunakan utamanya dalam hal penanganan Covid19 dan penyelamatan perekonomian.

Pemerintah daerah berperan penting dalam upaya penanganan pandemi Covid-19. Gubernur, bupati, dan walikota merupakan Ketua Gugus Tugas Percepatan Penanganan Covid19 yang berwenang untuk menetapkan kebijakan terkait penanganan pandemi di daerahnya masing-masing. Namun, kebijakan pemerintah daerah ini harus memperhatikan panduan penanganan dari pemerintah pusat, yang dalam hal ini diarahkan secara terpusat oleh Kementerian Dalam Negeri (Kemendagri).

Instrumen utama pemerintah daerah dalam penanganan Covid-19 adalah Anggaran Pendapatan dan Belanja Daerah (APBD). Salah satu kebijakan signifikan yang diambil oleh pemerintahan daerah dalam upaya penanganan Covid-19 adalah penetapan peraturan kepala daerah dengan tujuan dilakukannya penyesuaian APBD setelah proses refocusing kegiatan dan realokasi anggaran terkait pengadaan barang dan jasa dalam rangka percepatan penanganan Covid-19. Ketentuan yang menjadi dasar pemerintah daerah dalam penyesuaian APBD ini diatur dalam Peraturan Menteri Dalam Negeri (Permendagri) No. 20 Tahun 2020. Permendagri tersebut menyatakan bahwa Belanja Tidak Terduga (BTT) digunakan sebagai prioritas untuk penanganan Covid-19. Pemerintah daerah perlu menetapkan status darurat bencana terlebih dahulu agar dapat menggunakan alokasi BTT untuk keperluan penanganan Covid-19.

Refocusing dan realokasi anggaran dilakukan melalui optimalisasi penggunaan BTT (Instruksi Mendagri No. 1 Tahun 2020). Penyesuaian dilakukan terhadap pendapatan transfer ke daerah dan dana desa serta pendapatan asli daerah. Selain itu, dilakukan pula rasionalisasi terhadap belanja pegawai, belanja barang, dan belanja modal. Sementara itu, selisih lebih anggaran pendapatan dengan belanja yang telah disesuaikan dialokasikan utamanya untuk keperluan kesehatan, pengadaan program jaring pengamanan sosial (JPS), dan pemulihan perekonomian. Secara teknis, refocusing dan realokasi anggaran ini dijelaskan dalam Surat Keputusan Bersama Menteri Dalam Negeri dan Menteri Keuangan No. 119/2913/SJ No. 177/KMK.07/2020. Hasil refocusing dan realokasi anggaran yang dilakukan akan dituangkan dalam Perubahan APBD (P-APBD) yang kemudian disahkan oleh Dewan Perwakilan Rakyat Daerah (DPRD) dalam bentuk Peraturan Daerah (Perda) P-APBD. Pemerintah Daerah Kabupaten "ABC", rencana kerja anggaran perubahan perangkat daerah untuk BTT yang semula sejumlah Rp5.000.000.000,00 mengalami peningkatan sebesar Rp78.529.983.766,71 sehingga dalam Perda P-APBD Kabupaten "ABC" Tahun Anggaran 2020 menjadi sebesar Rp83.529.983.766,71.

Pelaksanaan anggaran belanja pemerintah diimplementasikan dalam tahapan-tahapan yang terdiri atas pembagian alokasi dan pengeluaran dana ke satuan kerja, pelaksanaan komitmen, akuisisi dan verifikasi barang/jasa, serta pembayaran (Schiavo-Campo, 2017). Kondisi darurat dan respon kebijakan yang mengikutinya mengakibatkan adanya perlakuan khusus dalam siklus pelaksanaan anggaran belanja terkait kebutuhan penanganan pandemi jika dibandingkan dengan kondisi biasa dan dengan belanja non-penanganan pandemi. Selain itu, terdapat beberapa pokok permasalahan yang dijumpai dalam laporan pemeriksaan Badan Pemeriksa Keuangan dalam lingkup pemerintah daerah yang menjadi sampel pemeriksaan (Susanto, 2021). Salah satu pokok permasalahan tersebut adalah tidak dilaksanakannya 


\section{JURNALKU}

Volume 1 No. 4, Desember 2021

rasionalisasi anggaran, refocusing dan realokasi sesuai dengan ketentuan yang ada sehingga perlu dilakukan penelaahan lebih lanjut terhadap pelaksanaan pada pemerintah daerah.

Secara umum, terdapat beberapa studi sebagaimana dilakukan Joyce \& Prabowo (2020) dan Kim (2020) yang telah mengkaji respon pemerintah dalam penanganan pandemi. Sanjaya (2020) meneliti penggunaan APBD sebagai instrumen utama bagi pemerintah daerah dalam penanganan Covid-19. Penelitian mengenai perlakuan akuntansi BTT pada pemerintah daerah telah dilakukan Sugiri (2021). Agnika dkk. (2021) meneliti kinerja APBD sebelum dan saat pandemi Covid-19. Dalam penelitian Basri dan Gunardi (2021) telah dibahas pengelolaan keuangan pemerintah daerah pada masa pandemi Covid-19 mulai dari proses penganggaran, penatausahaan, dan pertanggungjawaban. Berbeda dengan penelitian sebelumnya, penelitian ini mengeksplorasi kebijakan keuangan pemerintah daerah sekaligus dengan siklus pelaksanaan anggaran belanja untuk penanganan pandemi. Hasil studi ini bermanfaat sebagai pembelajaran respon kebijakan keuangan dalam kondisi darurat, sekaligus memberikan gambaran rangkaian aktivitas yang harus dilakukan dalam siklus pelaksanaan anggaran belanja pemerintah daerah, sehingga dapat bertindak secara lebih cepat apabila terjadi keadaan yang mendesak/darurat.

\section{KAJIAN PUSTAKA}

\section{Pengelolaan Keuangan Daerah}

Berdasarkan Peraturan Pemerintah (PP) No. 12 Tahun 2019, pemegang kekuasaan pengelolaan keuangan daerah diduduki oleh kepala daerah. Dalam melaksanakan kewenangannya, kepala daerah melimpahkan sebagian atau seluruh kekuasaannya kepada pejabat perangkat daerah yang terdiri atas sekretaris daerah (Sekda) selaku koordinator Pengelolaan Keuangan Daerah, kepala satuan kerja pengelola keuangan daerah (SKPKD) yang merupakan PPKD, dan kepala SKPD (Satuan Kerja Perangkat Daerah) sebagai pejabat pengguna anggaran/pengguna barang.

Kepala SKPD dalam pelaksanaan kewenangannya selaku pengguna anggaran dibantu oleh kuasa pengguna anggaran (KPA), Bendahara Penerimaan dan Pengeluaran, Pejabat Penatausahaan Keuangan SKPD (PPK-SKPD), serta Pejabat Pelaksana Teknis Kegiatan (PPTK). Jabatan PPK-SKPD, Bendahara, dan PPTK tidak boleh saling merangkap satu dengan lainnya. Jabatan PPK-SKPD, bendahara penerimaan, dan bendahara pengeluaran masingmasing hanya terdiri dari 1 (satu) orang di setiap SKPD sedangkan jabatan KPA dan PPTK dapat ditunjuk untuk setiap biro/bidang/bagian di dalam SKPD, sesuai kebutuhan organisasi.

Pelaksanaan akuntansi keuangan daerah diselenggarakan sebagai bentuk pertanggungjawaban atas APBD oleh SKPD selaku pengguna anggaran (PA) dan pejabat pengelola keuangan daerah (PPKD) selaku PA sekaligus bendahara umum daerah (BUD) yang bertujuan untuk menghasilkan laporan keuangan (Mulyana, 2014).

\section{Siklus Pelaksanaan Belanja Pemerintah Daerah}

Dalam Schiavo-Campo (2017), siklus pelaksanaan anggaran belanja pemerintah diimplementasikan dalam tahapan-tahapan yang terdiri atas pembagian alokasi dan pengeluaran dana ke satuan kerja, pelaksanaan komitmen, akuisisi dan verifikasi, serta pembayaran. Siklus pelaksanaan belanja pemerintah daerah terdiri atas dua tahapan, yaitu tahap persiapan dan tahap pelaksanaan/penatausahaan (Mulyana dan Sugiri, 2020). Pada tahap persiapan pelaksanaan APBD, sebelum APBD dapat dilaksanakan terdapat beberapa kegiatan yang perlu dilakukan yaitu penyusunan dan penetapan dokumen pelaksanaan anggaran (DPA) SKPD, anggaran kas, serta Surat Penyediaan Dana (SPD).

Setelah Rancangan APBD ditetapkan menjadi Perda APBD, Kepala SKPD menyusun DPA-SKPD sebagai dasar pelaksanaan anggaran yang merinci sasaran, program dan kegiatan, anggaran, serta perkiraan pendapatan dan rencana penarikan dana tiap-tiap SKPD. Berdasarkan 


\section{JURNALKU}

Volume 1 No. 4, Desember 2021

DPA-SKPD, Kepala SKPD menyusun rancangan anggaran kas untuk disampaikan kepada PPKD bersamaan dengan rancangan DPA-SKPD.

Pernyataan ketersediaan dana untuk melaksanakan kegiatan terdapat dalam SPD, yang akan digunakan sebagai dasar pengajuan Surat Permintaan Pembayaran (SPP). SPP diajukan oleh Bendahara Pengeluaran dan akan digunakan sebagai dasar dalam tahap berikutnya, yaitu pelaksanaan dan penatausahaan APBD.

Tahapan yang kedua adalah tahap pelaksanaan dan penatausahaan APBD yang terdiri atas pelaksanaan anggaran pendapatan daerah, belanja daerah, dan pembiayaan daerah. Setelah Dokumen Pelaksanaan Anggaran, aktivitas dalam siklus pelaksanaan belanja pemerintah adalah proses pembuatan komitmen. KPA dapat memberi kewenangan kepada PPK untuk melakukan tindakan yang berakibat pada pengeluaran anggaran belanja dan mengadakan perjanjian dengan pihak lain dalam batas anggaran belanja yang telah ditetapkan, yang dalam pelaksanaannya dapat dibantu oleh Pengelola Pengadaan Barang/Jasa.

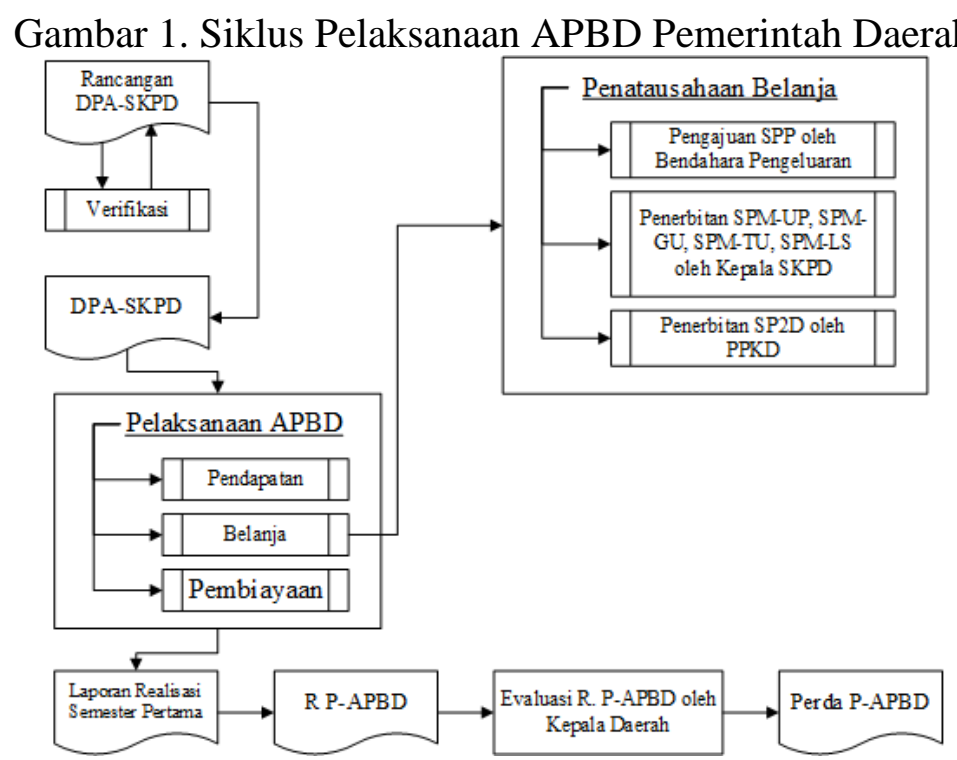

Sumber: diolah penulis dari Mulyana (2014)

Apabila pengadaan barang/jasa telah dilaksanakan, maka dilanjutkan dengan proses pembayaran atas barang/jasa yang dapat dilakukan melalui mekanisme pembayaran baik secara langsung melalui kas daerah maupun dengan uang persediaan yang dikelola oleh bendahara pengeluaran satuan kerja untuk kemudian dilakukan penerbitan SPP.

Berdasarkan PP No. 12 Tahun 2019, SPP diajukan oleh bendahara pengeluaran kepada PPK-SKPD untuk verifikasi berkas dan bukti kelengkapannya. Pengajuan SPP dilakukan dengan menyusun dokumen SPP yang dapat berupa SPP Uang Persediaan (SPP-UP), SPP Ganti Uang (SPP-GU), SPP Tambah Uang (SPP-TU), dan SPP Langsung (SPP-LS). SPP-LS terdiri atas LS untuk pembayaran gaji dan tunjangan serta LS untuk pengadaan barang dan jasa. Adapun penelitian ini berfokus pada transaksi pembayaran langsung (LS) dari Rekening Kas Umum Daerah (RKUD) ke penerima, yaitu pihak ketiga.

PPK-SKPD menyusun dokumen Surat Perintah Membayar (SPM) dari SPP yang diajukan untuk diserahkan dan disahkan oleh PA. SPM yang telah terbit disampaikan kepada BUD bersama dengan SPP. Kemudian, Kuasa BUD menerbitkan Surat Perintah Pencairan Dana (SP2D) apabila dokumen yang diajukan telah memenuhi syarat kelengkapan dan kesesuaian. 


\section{JURNALKU}

Volume 1 No. 4, Desember 2021

\section{Kebijakan Keuangan Daerah terhadap Pandemi Covid-19 \\ Percepatan Refocusing dan Realokasi Anggaran}

Instruksi Mendagri No. 1 Tahun 2020 memberikan arahan untuk dilakukannya percepatan penggunaan alokasi anggaran kegiatan tertentu (refocusing) dan/atau perubahan alokasi (realokasi) anggaran paling lambat 7 hari setelah Instruksi Mendagri ini ditetapkan. Refocusing dan realokasi anggaran ini digunakan untuk peningkatan kapasitas penanganan terkait kesehatan, penanganan dampak ekonomi, dan penyediaan jaring pengamanan sosial.

Percepatan refocusing dan realokasi ini dilakukan melalui optimalisasi BTT yang tersedia dalam APBD tahun anggaran 2020. Dalam hal BTT tidak mencukupi, pemerintah daerah melakukan penjadwalan ulang capaian program kegiatan untuk refocusing dan realokasi anggaran serta pemanfaatan uang kas yang tersedia, antara lain terhadap kegiatan yang bersumber dari dana transfer pemerintah pusat dan dana transfer antar daerah sesuai dengan ketentuan peraturan perundang-undangan, belanja modal yang kurang prioritas, kegiatan pembangunan sarana dan prasarana kelurahan dan pemberdayaan masyarakat di kelurahan, hasil rasionalisasi anggaran, pengeluaran pembiayaan dalam tahun anggaran berjalan, serta pemanfaatan dana yang berasal dari penerimaan daerah dalam APBD tahun anggaran 2020.

Selain itu, pemerintah daerah juga diwajibkan untuk melaporkan penggunaan dana untuk penanganan pandemi Covid-19 yang bersumber dari APBD untuk dilaporkan secara berkala apabila terjadi perubahan alokasi.

\section{Rasionalisasi Belanja}

Surat Keputusan Bersama Menteri Dalam Negeri dan Menteri Keuangan Nomor 119/2813/SJ Nomor 177/KMK.07/2020 mengatur bahwa Kepala Daerah perlu melakukan penyesuaian target pendapatan dan belanja daerah dalam APBD dalam rangka penanganan Covid-19. Penyesuaian ini dilakukan dengan terlebih dahulu melakukan perubahan Perda tentang Penjabaran APBD tahun anggaran 2020 dengan pemberitahuan kepada Pimpinan DPRD, untuk selanjutnya dituangkan dalam Perda P-APBD 2020 atau ditampung dalam Laporan Realisasi Anggaran (LRA).

Penyesuaian belanja daerah dilakukan melalui rasionalisasi terhadap akun belanja pegawai, barang/jasa dan belanja modal. Rasionalisasi belanja pegawai melalui perubahan besaran tunjangan dan pengendalian/pengurangan pengeluaran untuk honorarium kegiatan, honorarium pengelola dana bos, serta uang lembur. Rasionalisasi belanja barang/jasa sekurangkurangnya sebesar 50\% dengan mengurangi anggaran belanja. Adapun rasionalisasi belanja modal sekurang-kurangnya sebesar 50\% dengan mengurangi anggaran belanja.

\section{Penggunaan BTT untuk Penanganan Covid-19}

Berdasarkan Permendagri No. 20 Tahun 2020, pemerintah daerah dapat melakukan pengeluaran yang belum tersedia anggarannya untuk penanganan Covid-19 dengan pembebanan langsung pada belanja tidak terduga (BTT) untuk diusulkan dalam rancangan PAPBD. Apabila BTT tidak mencukupi, pemerintah daerah menggunakan dana dari hasil penjadwalan ulang capaian program dan kegiatan lainnya (melalui perubahan DPA-SKPD paling lama sehari) serta pengeluaran pembiayaan dalam tahun anggaran berjalan; dan/atau pemanfaatan uang kas yang tersedia.

Permendagri No. 77 Tahun 2020 telah mengatur tata cara penggunaan BTT untuk keadaan darurat dan keperluan mendesak. Penggunaan BTT diformulasikan terlebih dahulu dalam rencana kerja (dalam hal anggaran belum tersedia) dan Perubahan DPA-SKPD (dalam hal anggaran belum tercukupi). Dokumen-dokumen tersebut akan dijadikan dasar dalam menetapkan P-APBD. Adapun siklus belanja untuk keperluan penanganan pandemi Covid-19 pada Pemda dapat diklasifikasikan menjadi 2, yaitu untuk keperluan mendesak yang belum tersedia anggarannya dan untuk keperluan yang telah tersedia anggarannya. 


\section{JURNALKU}

Volume 1 No. 4, Desember 2021

Untuk keperluan mendesak yang belum tersedia anggarannya terdiri dari dua tahap, yaitu penyusunan Rencana Kebutuhan Belanja (RKB) dan pencairan dana. Penyusunan rencana kebutuhan belanja (RKB) dilakukan setelah ditetapkan status tanggap darurat melalui peraturan perundang-undangan, SKPD menyusun RKB untuk dijadikan sebagai dasar usulan penggunaan BTT untuk keperluan mendesak yang belum tersedia anggarannya. RKB yang disusun memuat besaran kebutuhan belanja yang akan diajukan dan rencana penggunaan. RKB ini kemudian disampaikan oleh Kepala SKPD kepada PPKD. Sedangkan tahapan pencairan dana, yaitu dana tanggap darurat bencana dicairkan oleh PPKD selaku BUD paling lama 1 (satu) hari setelah diterimanya RKB. Pencairan dana dilakukan dengan mekanisme tambahan uang persediaan (TU) yang diserahkan kepada bendahara pengeluaran SKPD atau pembayaran secara langsung (LS) yang diserahkan kepada pihak ketiga. Penggunaan dana darurat bencana dicatat oleh bendahara pengeluaran dalam buku kas umum dan dibebankan dalam BTT.

Untuk keperluan yang telah tersedia anggarannya maka pelaksanaan belanja tidak terduga apabila telah tersedia anggarannya akan sama seperti siklus belanja pemerintah daerah pada umumnya, mulai dari pembentukan komitmen yang dilanjutkan pengajuan SPP oleh Bendahara Pengeluaran, kemudian pengajuan SPM oleh SKPD kepada PPKD dan dilanjutkan dengan penerbitan SP2D oleh PPKD.

\section{Penelitian Sebelumnya}

Respon pemerintah dalam penanganan pandemi Covid-19 menjadi topik yang menarik untuk diteliti. Secara umum, terdapat beberapa studi yang telah dilakukan. Joyce \& Prabowo (2020) menemukan bahwa pemerintah dalam berbagai level telah merespon kondisi pademi covid-19 dengan segera, terutama dalam bidang kesehatan dan pemulihan dampak ekonomi akibat pandemi. Kim (2020) telah mengkaji respon pemerintah dalam penanganan pandemi Covid-19 dengan menerapkan karantina secara tegas untuk mencegah penyebaran virus. Selain itu, pengeluaran pemerintah yang dilaksanakan secara tepat waktu akan dapat memperbaiki krisis ekonomi yang disebabkan oleh pandemi.

Terkait dengan respon yang dilakukan pemerintah daerah, Sanjaya (2020) meneliti penggunaan APBD sebagai instrumen utama bagi pemerintah daerah dalam penanganan Covid19 harus dilakukan berdasarkan ketentuan dan arahan dari pemerintah pusat, yang diantaranya melalui refocusing dan realokasi anggaran untuk lebih fokus dalam bidang kesehatan, pemulihan ekonomi, dan jaring pengaman sosial. Sugiri (2021) mendalami tentang pelaksanaan akuntansi BTT pada pemerintah daerah yang jarang digunakan pada kondisi normal. Perlakuan akuntansi tersebut meliputi pengakuan, pengukuran, dan penyajian dalam laporan keuangan. Agnika et. al (2021) meneliti kinerja APBD sebelum dan saat pandemi Covid-19 yang menunjukkan bahwa anggaran belanja modal mengalami penurunan karena dialokasikan sebagian untuk penanggulangan pandemi. Perubahan APBD dilaksanakan agar target dan realisasi anggaran lebih sesuai dengan kondisi pandemi.

Adapun penelitian yang dilakukan oleh Basri dan Gunardi (2021) membahas pengelolaan keuangan pemerintah daerah pada masa pandemi Covid-19 mulai dari proses penganggaran dengan dilaksanakannya refocusing dan realokasi anggaran secara beberapa kali, serta proses penatausahaan dan pertanggungjawaban yang memiliki kendala pada perlakuan BTT karena masih belum memiliki petunjuk teknis. Penelitian ini secara sekaligus mengeksplorasi kebijakan keuangan dan rangkaian aktivitas yang dilakukan dalam siklus pelaksanaan anggaran belanja pemerintah daerah untuk penanganan pandemi Covid-19 yang fokusnya pada transaksi pembayaran LS dari RKUD ke pihak ketiga sebagai penerima.

\section{METODE}

Penelitian ini menggunakan pendekatan kualitatif yang menganalisis kata-kata yang menyatakan alasan-alasan atau interpretasi atau makna-makna dan kejadian-kejadian serta 


\section{JURNALKU}

Volume 1 No. 4, Desember 2021

perbuatan-perbuatan yang dilakukan perorangan atau kelompok sosial. Metode pengumpulan data yang digunakan yaitu metode studi kepustakaan, observasi, dan wawancara pada Badan Keuangan Daerah Kabupaten "ABC” untuk kemudian diolah secara kualitatif.

Studi kepustakaan digunakan untuk melakukan peninjauan teori dari artikel ilmiah, peraturan, buku, dan sumber yang terkait. Adapun kegiatan observasi dilakukan dengan melakukan pengamatan secara langsung terkait proses dan penggunaan aplikasi yang digunakan dalam siklus belanja pemerintah daerah Kabupaten "ABC". Sementara itu, kegiatan wawancara dilakukan kepada pihak yang terlibat dan memiliki peran dalam siklus belanja pemerintah daerah Kabupaten "ABC" yang dilaksanakan pada tahun anggaran 2020. Penelitian ini menggunakan model analisis interaktif, dengan tahapan kondensasi data, penyajian data, dan penarikan kesimpulan (Matthew dkk., 2014). Kondensasi data mencakup upaya melakukan abstraksi dan mengubah hasil studi pustaka, hasil wawancara, dan temuan di lapangan menjadi lebih padat. Data hasil kondensasi tersebut disajikan dan tahap terakhir disusun kesimpulan.

\section{HASIL DAN PEMBAHASAN}

\section{Penerapan Kebijakan Penanganan Covid-19 pada Pemerintah Daerah Kabupaten "ABC"}

\section{Pembentukan Gugus Tugas Percepatan Penanganan Covid-19}

Keputusan Bupati "ABC" No. 188.45/207/406/001/3/2020 tentang Gugus Tugas Percepatan Penanganan Covid-19 memutuskan untuk membentuk gugus tugas percepatan penanganan pandemi Covid-19 dalam rangka upaya peningkatan kesiapsiagaan untuk menghadapi dan mencegah penyebaran Covid-19. Gugus tugas tersebut terdiri atas bidang pendidikan, perhubungan, informasi dan komunikasi, pariwisata, pemerintahan, kesehatan, dan ekonomi.

Gambar 2. Susunan Anggota Gugus Tugas Percepatan Penganganan Covid-19 Pemerintah

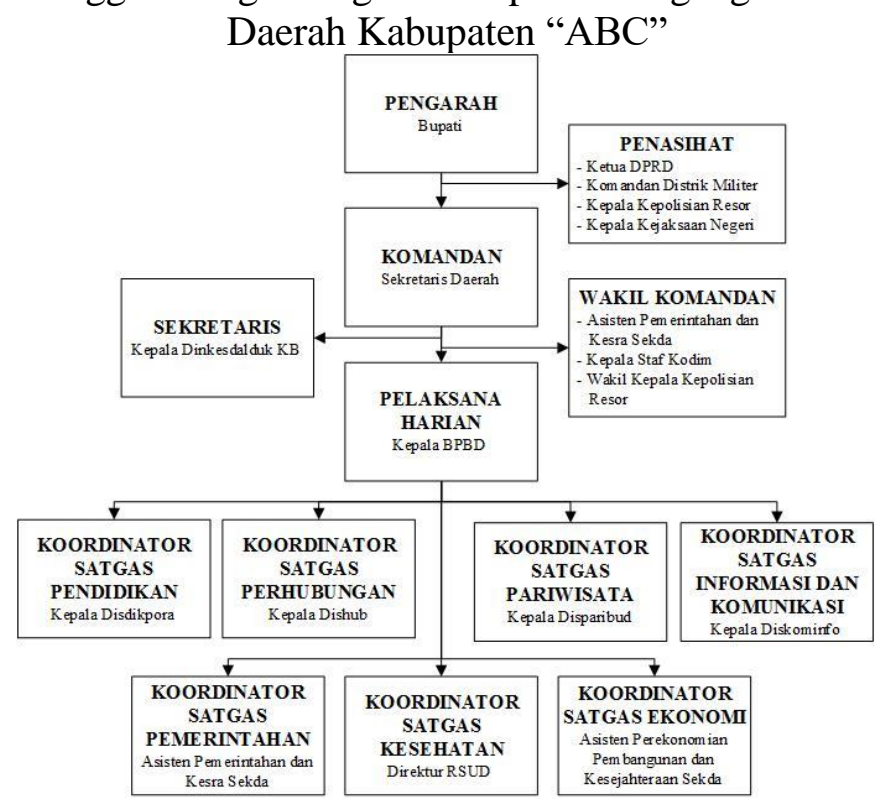

Sumber: diolah penulis dari Keputusan Bupati “ABC” No.188.45/207/406/001/3/2020

Kebijakan Keuangan Pemerintah Daerah Kabupaten “ABC” terhadap Pandemi Covid-19 Percepatan refocusing/realokasi anggaran

Pandemi Covid-19 mengharuskan Pemerintah Daerah Kabupaten "ABC" untuk melaksanakan refocusing dan/atau realokasi anggaran yang digunakan dalam rangka meningkatkan kapasitas penanganan kesehatan dan dampak ekonomi. Optimalisasi BTT yang 
tersedia dalam APBD tahun anggaran 2020 seharusnya dilakukan dalam rangka percepatan refocusing dan realokasi anggaran ini.

Namun, dana BTT dalam anggaran terlalu kecil untuk penanganan Covid-19. Oleh karena itu, Pemerintah Daerah Kabupaten "ABC" menjadwal ulang capaian program kegiatan. Adapun anggaran untuk penanganan Covid-19 dengan melakukan efisiensi APBD tahun anggaran 2020 yang dilakukan Kabupaten "ABC” mencapai angka Rp400 miliar.

\section{Rasionalisasi Anggaran}

Rasionalisasi anggaran pendapatan dilakukan dengan menyesuaikan target pendapatan daerah sesuai dengan potensi pendapatan pajak dan retribusi daerah pada masa pandemi Covid19. Rasionalisasi anggaran pada Pemerintah Daerah Kabupaten "ABC" dituangkan dalam Perda P-APBD.

Perubahan APBD dilakukan sebanyak dua kali, yakni dalam Perda Kabupaten "ABC" No. 8 Tahun 2020 yang disahkan pada tanggal 31 Agustus 2020, dan Perda Kabupaten "ABC" No. 10 Tahun 2020 yang ditetapkan pada tanggal 19 Oktober 2020.

Tabel 1. menunjukkan bahwa jumlah anggaran belanja daerah pada Kabupaten "ABC" disesuaikan sehingga belanja tidak langsung bertambah dan belanja langsung berkurang. Belanja tidak langsung bertambah dikarenakan penambahan alokasi Belanja Tidak Terduga yang sangat signifikan.

Tabel 1. Belanja Daerah Kabupaten "ABC” Tahun Anggaran 2020 dalam APBD, P-APBD, dan Realisasi (dalam Rp)

\begin{tabular}{|l|r|r|r|}
\hline & \multicolumn{1}{|c|}{ APBD 2020 } & \multicolumn{1}{c|}{ P-APBD 2020 } & \multicolumn{1}{c|}{ Realisasi } \\
\hline Belanja Tidak Langsung & $\mathbf{1 . 1 8 9 . 9 4 4 . 5 4 9 . 9 4 6 , 0 0}$ & $\mathbf{1 . 2 2 2 . 9 6 5 . 7 5 3 . 1 0 1 , 7 1}$ & $\mathbf{1 . 1 5 8 . 1 9 8 . 3 6 7 . 1 2 4 , 8 0}$ \\
\hline Belanja Pegawai & $818.172 .367 .346,00$ & $777.189 .688 .390,00$ & $735.392 .362 .366,80$ \\
\hline Belanja Hibah & $86.713 .332 .000,00$ & $83.833 .456 .145,00$ & $82.255 .597 .996,00$ \\
\hline Belanja Bantuan Sosial & $9.103 .680 .000,00$ & $5.203 .680 .000,00$ & $4.384 .080 .000,00$ \\
\hline Belanja Bagi Hasil & $8.430 .352 .600,00$ & $6.322 .466 .800,00$ & $4.964 .174 .115,00$ \\
\hline Belanja Bantuan Keuangan & $262.524 .818 .000,00$ & $266.886 .478 .000,00$ & $265.611 .417 .292,00$ \\
\hline Belanja Tidak Terduga & $5.000 .000 .000,00$ & $83.529 .983 .766,71$ & $65.590 .735 .355,00$ \\
\hline Belanja Langsung & $\mathbf{8 8 5 . 0 8 6 . 7 4 8 . 2 5 4 , 0 0}$ & $\mathbf{7 8 9 . 8 9 2 . 1 4 4 . 9 3 8 , 0 0}$ & $\mathbf{7 0 3 . 7 8 9 . 4 2 4 . 6 0 4 , 5 4}$ \\
\hline Belanja Pegawai & $133.778 .931 .900,00$ & $149.085 .539 .891,23$ & $138.048 .172 .209,00$ \\
\hline Belanja Barang dan Jasa & $432.202 .794 .427,00$ & $380.569 .185 .628,89$ & $334.396 .400 .317,31$ \\
\hline Belanja Modal & $319.105 .021 .927,00$ & $260.237 .419 .417,88$ & $231.344 .852 .078,23$ \\
\hline
\end{tabular}

Sumber: diolah penulis dari APBD, P-APBD, dan BPS Kabupaten "ABC"

Selain itu, alokasi belanja langsung berkurang dikarenakan pengurangan belanja barang dan jasa serta belanja modal sesuai dengan arahan SKB Mendagri dan Menkeu. Namun, realisasi belanja daerah di bawah anggaran belanja baik sebelum perubahan maupun setelah perubahan.

\section{Penggunaan BTT untuk penanganan Covid-19}

Awalnya, BTT dialokasikan sebesar Rp5.000.000.000,00 pada APBD 2020 Pemerintah Daerah Kabupaten “ABC”. Jumlah ini belum mempertimbangkan penyebaran Covid-19 yang baru diumumkan bulan Maret 2020. Untuk menangani dampak pandemi, Pemerintah Daerah Kabupaten "ABC" membebankan belanja untuk penanganan Covid-19 ke dalam BTT melalui metode pembayaran TU dan LS. Namun, dikarenakan anggaran yang belum tersedia, PPKD melakukan pengajuan dana untuk dicairkan. Adapun pengajuan dana ini dilakukan dengan merumuskan penggunaan BTT dalam DPA-PPKD yang kemudian dijadikan Dokumen Pelaksanaan Perubahan Anggaran (DPPA) PPKD untuk dituangkan dalam P-APBD 2020.

BTT dalam P-APBD 2020 dialokasikan pada PPKD sebesar Rp83.529.983.766,71 untuk kemudian dilaksanakan oleh Organisasi Perangkat Daerah (OPD) yang memiliki fungsi terkait penanganan dan penanggulangan dampak akibat Covid-19, sebagaimana gugus tugas percepatan penanganan Covid-19. Mekanisme penggunaan BTT pada Pemerintah Daerah 


\section{JURNALKU}

Volume 1 No. 4, Desember 2021

Kabupaten "ABC" pada tahun anggaran 2020 telah sesuai dengan ketentuan dalam Permendagri No. 77 Tahun 2020.

Penyerapan belanja tidak terduga adalah sebesar Rp65.590.735.355,00. Realisasi BTT ini paling banyak digunakan untuk pemulihan dampak ekonomi yang diakibatkan oleh pandemi Covid-19, seperti bantuan terhadap korban terjangkit dan pemberian stimulus terhadap UMKM. Siklus Pelaksanaan Belanja Pemerintah Daerah Kabupaten "ABC" pada Masa Pandemi Covid-19

\section{Untuk Keperluan Non-Penanganan Pandemi Covid-19}

Belanja daerah untuk keperluan non-penanganan pandemi Covid-19 adalah pengeluaran yang dilaksanakan oleh Pemerintah Daerah Kabupaten "ABC" untuk jenis belanja secara umum yang sama seperti belanja pada kondisi normal.

Tugas sebagai Pejabat Pengelola Keuangan Daerah (PPKD) dilaksanakan oleh Kepala Badan Keuangan Daerah (Bakeuda) Kabupaten "ABC" selaku Bendahara Umum Daerah (BUD). Rincian siklus pelaksanaan belanja Pemerintah Daerah Kabupaten "ABC" untuk keperluan non-penanganan pandemi Covid-19 adalah sebagai berikut.

\section{Tahap Persiapan Pelaksanaan APBD}

Penyusunan dan penetapan DPA-SKPD

Setelah ditetapkan APBD melalui peraturan daerah, PPKD dalam waktu yang paling lama 3 (tiga) hari kerja memberitahukan kepada semua kepala SKPD untuk melaksanakan penyusunan DPA-SKPD. Kepala SKPD kemudian menyerahkan rancangan DPA-SKPD kepada PPKD paling lama 6 (enam) hari kerja setelah pemberitahuan untuk kemudian diverifikasi secara bersama-sama oleh TAPD dan Kepala SKPD paling lama 15 (lima belas) hari kerja setelah penetapan peraturan kepala daerah tentang penjabaran APBD.

Setelah dilakukan verifikasi, PPKD mengesahkan rancangan DPA-SKPD dengan persetujuan Sekda. Berikutnya, DPA-SKPD disampaikan kepada kepala SKPD yang bersangkutan, Inspektorat Kabupaten "ABC", dan Badan Pemeriksa Keuangan paling lama 7 (tujuh) hari kerja sejak tanggal pengesahan.

Penyusunan dan penetapan anggaran kas

Rancangan DPA-SKPD yang disusun oleh Kepala SKPD dijadikan dasar untuk penyusunan rancangan anggaran kas SKPD. Rancangan anggaran kas SKPD ini akan diserahkan kepada PPKD untuk dibahas oleh TAPD dan kepala SKPD secara bersamaan dengan rancangan DPA-SKPD. Kemudian, PPKD menyusun anggaran kas Pemerintah Daerah untuk pendanaan yang tercantum dalam DPA-SKPD yang telah disahkan. Ini akan digunakan dalam pembuatan SPD.

Penyusunan dan penetapan SPD

Setelah DPA-SKPD dan anggaran kas SKPD diterima, Kuasa BUD yaitu Kepala Bidang Anggaran Bakeuda "ABC" menyiapkan dokumen SPD sebagai dasar penyediaan dana untuk pelaksanaan APBD. Dokumen SPD ini kemudian disampaikan kepada PPKD untuk diotorisasi. SPD yang telah diotorisasi diserahkan kepada Kepala SKPD selaku PA.

\section{Tahap Pelaksanaan Belanja APBD}

\section{Pembuatan komitmen}

Kewenangan KPA untuk mengadakan perjanjian dengan pihak lain dalam batas anggaran belanja yang telah ditetapkan dapat didelegasikan kepada PPK atau PPTK. Bukti komitmen seperti dokumen kontrak digunakan sebagai salah satu dokumen pendukung pengajuan SPP.

\section{Serah Terima Barang/Jasa}

Setelah komitmen dibuat, dapat dilakukan serah terima barang/jasa yang pelaksanaanya dapat dibantu Pengelola Pengadaan Barang/Jasa. Dokumen yang dihasilkan adalah Berita Acara Serah Terima (BAST) Barang/Jasa. 


\section{JURNALKU}

Volume 1 No. 4, Desember 2021

\section{Pengajuan dokumen SPP}

Proses pembayaran belanja daerah secara langsung (LS) diawali dengan pengajuan SPPLS berdasarkan SPD untuk pelaksanaan program/kegiatan SKPD. PPTK menyiapkan dokumen pendukung pengajuan SPP, diantaranya berita acara dan dokumen pengadaan. Draf SPP dan lampiran dokumen pendukungnya diserahkan kepada bendahara pengeluaran SKPD untuk kemudian diverifikasi kelengkapan dan kesesuaiannya.

Bendahara menyampaikan draf SPP kepada kepala subbagian keuangan SKPD selaku PPK-SKPD paling lambat 3 (tiga) hari sejak diterima dokumen pendukung dari PPTK. Selanjutnya, PPK-SKPD meneliti kelengkapan dan kesesuaian berkas SPP yang berikutnya diserahkan kepada Kepala SKPD untuk disahkan. Adapun pengajuan SPP dilakukan melalui aplikasi Simda Keuangan dan berkasnya diserahkan kepada Bakeuda "ABC".

Pengajuan dokumen SPM

Pembuatan SPM dilakukan setelah PPK-SKPD melakukan verifikasi terhadap dokumen SPP. SPM diserahkan kepada Kepala SKPD untuk diotorisasi. Berkas SPM yang telah disahkan diajukan kepada BUD, baik melalui penyerahan berkas secara langsung ke Bakeuda "ABC" maupun melalui aplikasi Simda Keuangan.

Penerbitan dokumen SP2D

SPM yang diajukan oleh SKPD akan diverifikasi oleh Kepala Bidang Perbendaharaan Bakeuda "ABC" selaku Kuasa BUD. Apabila berkas belum sesuai, maka berkas akan dikembalikan kepada SKPD disertai catatan perbaikan. Perbaikan berkas dilakukan paling lambat 2 (dua) hari kerja. Namun, jika berkas lengkap, maka berkas diteruskan untuk penerbitan SP2D oleh Kuasa BUD beserta pengesahan cek yang diserahkan kepada penerima (pihak ketiga).

Tabel 2. Aktivitas dan Aliran Data Siklus Belanja Pemerintah Daerah Kabupaten "ABC"

\begin{tabular}{|c|c|c|}
\hline Aktivitas & Data Masukan & Data Keluaran \\
\hline \multicolumn{3}{|c|}{ 1. Tahap Persiapan Pelaksanaan APBD } \\
\hline $\begin{array}{l}\text { Penyusunan dan Penetapan } \\
\text { DPA-SKPD }\end{array}$ & - Surat pemberitahuan & - DPA \\
\hline $\begin{array}{l}\text { Penyusunan dan Penetapan } \\
\text { Anggaran Kas }\end{array}$ & - DPA & - Anggaran Kas Daerah \\
\hline $\begin{array}{l}\text { Penyusunan dan Penetapan } \\
\text { SPD }\end{array}$ & \begin{tabular}{|l} 
- DPA \\
- Anggaran Kas Daerah \\
\end{tabular} & - SPD \\
\hline \multicolumn{3}{|c|}{ 2. Tahap Pelaksanaan APBD } \\
\hline Pembuatan Komitmen & $\begin{array}{l}\text { - Salinan SPD } \\
\text { - Berkas pelaksanaan komitmen }\end{array}$ & - Dokumen pengadaan \\
\hline Serah Terima Barang/Jasa & - Dokumen pengadaan & $\begin{array}{l}\text { - BAST \& dokumen pengadaan } \\
\text { (Berkas pendukung pengajuan SPP) }\end{array}$ \\
\hline Pengajuan SPP & $\begin{array}{l}\text { - Salinan SPD } \\
\text { - Berkas pendukung pengajuan SPP }\end{array}$ & - SPP \& berkas pendukung \\
\hline Pengajuan SPM & - SPP \& berkas pendukung & - SPM \& berkas pendukung \\
\hline Penerbitan SP2D & $\begin{array}{l}\text { - SPP \& berkas pendukung } \\
\text { - SPM \& berkas pendukung }\end{array}$ & $\begin{array}{l}- \text { SP2D } \\
\text { - Cek }\end{array}$ \\
\hline
\end{tabular}

\section{Sumber: diolah penulis}

Penerbitan SP2D menandai realisasi pengeluaran dari rekening kas daerah. Oleh karena itu, bendahara pengeluaran melakukan pencatatan transaksi belanja dalam dokumen penatausahaan pengeluaran APBD.

\section{Untuk Keperluan Penanganan Pandemi Covid-19}

Pemerintah daerah dapat melakukan pengeluaran yang belum tersedia anggarannya dalam rangka antisipasi dan penanganan Covid-19. Pengeluaran ini diusulkan dalam rancangan P-APBD melalui pembebanan langsung pada belanja tidak terduga (BTT) dengan adanya mekanisme refocusing dan/atau realokasi anggaran dengan penyediaan dana melalui rasionalisasi anggaran. 


\section{JURNALKU}

Volume 1 No. 4, Desember 2021

Berdasarkan Perda Kabupaten "ABC" No. 3 Tahun 2014, penganggaran dan penatausahaan BTT hanya dapat dilakukan pada belanja SKPKD. Namun, dalam praktik penanganan pandemi Covid-19, meskipun penganggaran BTT hanya terdapat pada DPA-PPKD yaitu Bakeuda "ABC" selaku BUD, penatausahaan BTT dilaksanakan oleh SKPD/OPD yang tergabung dalam gugus tugas percepatan penanganan Covid-19.

Penerapan siklus pelaksanaan belanja untuk menangani Covid-19 pada Pemerintah Daerah Kabupaten "ABC" melibatkan proses refocusing dan realokasi anggaran yang telah dituangkan dalam aktivitas perubahan APBD tahun anggaran 2020. Anggaran untuk keperluan penanganan pandemi Covid-19 baru tersedia setelah ditetapkannya Perda P-APBD tersebut. Oleh karena itu, pelaksanaan belanja kebutuhan penanganan Covid-19 pada Pemerintah Daerah Kabupaten "ABC" termasuk ke dalam belanja yang belum tersedia anggarannya. Adapun aktivitas pada siklus pelaksanaan belanja untuk keperluan penanganan pandemi Covid-19 dapat diuraikan sebagai berikut.

\section{Tahap Persiapan Pelaksanaan APBD}

\section{Penyesuaian Dokumen Pelaksanaan Anggaran}

Untuk belanja kebutuhan penanganan pandemi Covid-19, perlu dilakukan penyesuaian terhadap dokumen pelaksanaan anggaran. Sekda memberitahukan kepada para Kepala OPD untuk segera merancang penyesuaian terhadap dokumen yang diperlukan dalam pelaksanaan anggaran dengan tujuan untuk segera menyelesaikan proses refocusing dan realokasi anggaran.

Sementara itu, Kepala OPD yang bertugas secara langsung dalam penanganan Covid19 mengajukan dokumen RKB yang menunjukkan jumlah kebutuhan belanja darurat dalam jangka waktu tertentu. Pengajuan dokumen RKB diawali oleh Badan Penanggulangan Bencana Daerah (BPBD) pada awal penyebaran Covid-19 dan diikuti oleh OPD lainnya yang tergabung dalam Gugus Tugas Percepatan Penanganan Covid-19 dengan Keputusan Bupati Kabupaten "ABC" No. 188.45/207/406/001/3/2020.

Berdasarkan RKB dan hasil refocusing dan realokasi anggaran, PPKD dapat menyusun perubahan DPA-PPKD untuk menambah jumlah BTT. Dokumen yang dihasilkan adalah DPPA-PPKD.

\section{Penyesuaian anggaran kas}

Hasil refocusing dan realokasi anggaran akan dituangkan dalam perubahan APBD dengan ditetapkannya Perda Kabupaten "ABC" No. 10 Tahun 2020. Setelah penetapan Perda P-APBD, dokumen pelaksanaan anggaran hasil penyesuaian segera disahkan untuk menyusun anggaran kas daerah yang baru. Dokumen-dokumen tersebut akan digunakan dalam pembuatan SPD.

\section{Penyesuaian SPD}

Dokumen terkait pelaksanaan anggaran ini terdiri atas DPPA dan Anggaran Kas Daerah, yang menjadi dasar penerbitan SPD. Penyesuaian terhadap dokumen-dokumen tersebut menunjukkan bahwa anggaran dalam rangka penanganan Covid-19 telah tersedia untuk pelaksanaan pengadaan barang/jasa pemerintah daerah. Adapun hasil perubahan dokumen terkait pelaksanaan anggaran diserahkan kepada PPKD untuk diotorisasi.

\section{Tahap Pelaksanaan Belanja APBD}

\section{Pembuatan Komitmen Berdasarkan Hasil Perubahan Anggaran}

Pengadaan barang/jasa untuk keperluan penanganan pandemi Covid-19 dilakukan oleh OPD yang secara fungsional memiliki tanggung jawab dalam penggunaan anggaran terkait penanganan Covid-19. Namun, penatausahaan BTT hanya terdapat pada anggaran SKPKD. Pembuatan komitmen dapat dilaksanakan oleh PPK atau PPTK yang telah diberi kewenangan dari KPA. Berkas pelaksanaan komitmen menjadi bagian dari dokumen pengadaan. 


\section{JURNALKU}

Volume 1 No. 4, Desember 2021

\section{Serah Terima Barang/Jasa}

Jika komitmen telah dibuat, serah terima barang/jasa dapat dilaksanakan dengan bantuan Pengelola Pengadaan Barang/Jasa. Aktivitas ini menghasilkan BAST Barang/Jasa yang akan digunakan sebagai dokumen pendukung pengajuan SPP bersama dengan dokumendokumen pengadaan.

\section{Pengajuan dokumen SPP}

PPTK menyiapkan dokumen pendukung SPP-LS terkait kegiatan untuk kemudian diteliti oleh bendahara pengeluaran. Dokumen SPP diajukan kepada PPKD melalui PPK-SKPKD untuk diverifikasi terlebih dahulu. Transaksi pengeluaran yang akan dilaksanakan tidak boleh melebihi batas yang tercantum dalam dokumen anggaran hasil perubahan.

Pengajuan dokumen SPM

PPK-SKPKD melakukan verifikasi terhadap dokumen SPP sebelum menyusun dokumen SPM. Dokumen-dokumen tersebut kemudian diserahkan kepada PPKD untuk disahkan. Berkas SPM yang telah diotorisasi diajukan kepada BUD bersamaan dengan berkas SPP kepada Bakeuda "ABC” melalui aplikasi Simda Keuangan agar lebih cepat diproses.

Tabel 3. Aktivitas dan Aliran Data dalam Siklus Belanja Pemerintah Daerah Kabupaten

"ABC" Keperluan Penanganan Covid-19

\begin{tabular}{|c|c|c|}
\hline Aktivitas & Data Masukan & Data Keluaran \\
\hline \multicolumn{3}{|c|}{ 1. Tahap Persiapan Pelaksanaan APBD } \\
\hline $\begin{array}{l}\text { Penyesuaian Dokumen } \\
\text { Pelaksanaan Anggaran }\end{array}$ & - Surat pemberitahuan & - DPPA \\
\hline Penyesuaian Anggaran Kas & - DPPA & $\begin{array}{l}\text { - Anggaran Kas Daerah } \\
\text { (hasil penyesuaian) }\end{array}$ \\
\hline Penyesuaian SPD & $\begin{array}{l}\text { - DPPA } \\
\text { - Anggaran Kas Daerah }\end{array}$ & $\begin{array}{l}\text { - SPD } \\
\text { (hasil penyesuaian) }\end{array}$ \\
\hline \multicolumn{3}{|c|}{ 2. Tahap Pelaksanaan APBD } \\
\hline $\begin{array}{l}\text { Pembuatan Komitmen } \\
\text { Berdasarkan Hasil Perubahan } \\
\text { Anggaran }\end{array}$ & $\begin{array}{l}\text { - Salinan SPD (hasil penyesuaian) } \\
\text { - Berkas pelaksanaan komitmen }\end{array}$ & - Dokumen pengadaan \\
\hline Serah Terima Barang/Jasa & - Dokumen pengadaan & $\begin{array}{l}\text { - BAST \& dokumen pengadaan } \\
\text { (Berkas pendukung pengajuan SPP) }\end{array}$ \\
\hline Pengajuan Dokumen SPP & $\begin{array}{l}\text { - Salinan SPD (hasil penyesuaian) } \\
\text { - Berkas pendukung pengajuan SPP }\end{array}$ & - SPP \& berkas pendukung \\
\hline Pengajuan Dokumen SPM & - SPP \& berkas pendukung & - SPM \& berkas pendukung \\
\hline $\begin{array}{l}\text { Pencairan Dana Melalui } \\
\text { Penerbitan SP2D }\end{array}$ & $\begin{array}{l}\text { - SPP \& berkas pendukung } \\
\text { - SPM \& berkas pendukung }\end{array}$ & $\begin{array}{l}-\mathrm{SP} 2 \mathrm{D} \\
\text { - Cek }\end{array}$ \\
\hline
\end{tabular}

\section{Pencairan Dana melalui Penerbitan SP2D}

\section{Sumber: diolah penulis}

Untuk menjamin keakuratan dan kelengkapan dokumen, Bakeuda "ABC" melakukan proses verifikasi terhadap SPP dan SPM yang diajukan. Proses ini dilakukan oleh Bidang Perbendaharaan selaku Kuasa BUD. Berkas yang memenuhi ketentuan akan diteruskan untuk dilakukan penerbitan SP2D oleh Kuasa BUD yang kemudian diotorisasi oleh PPKD bersamaan dengan cek yang akan diserahkan kepada pihak ketiga. Bendahara pengeluaran PPKD mencatat transaksi BTT setelah menerima SP2D yang telah disahkan.

Keperluan penanganan pandemi Covid-19 yang secara umum bersifat mendesak mempersingkat waktu pemrosesan verifikasi dokumen SPP/SPM dan penerbitan SP2D, yaitu pada hari yang sama saat dokumen diajukan.

Secara detail alur proses dalam siklus pelaksanaan anggaran belanja pemerintah daerah untuk keperluan penanganan pandemi Covid-19 digambarkan sebagai berikut pada Gambar 3 . 
Gambar 3. Bagan Alir Tahap Pelaksanaan Anggaran Belanja Daerah untuk Keperluan Penanganan Pandemi Covid-19

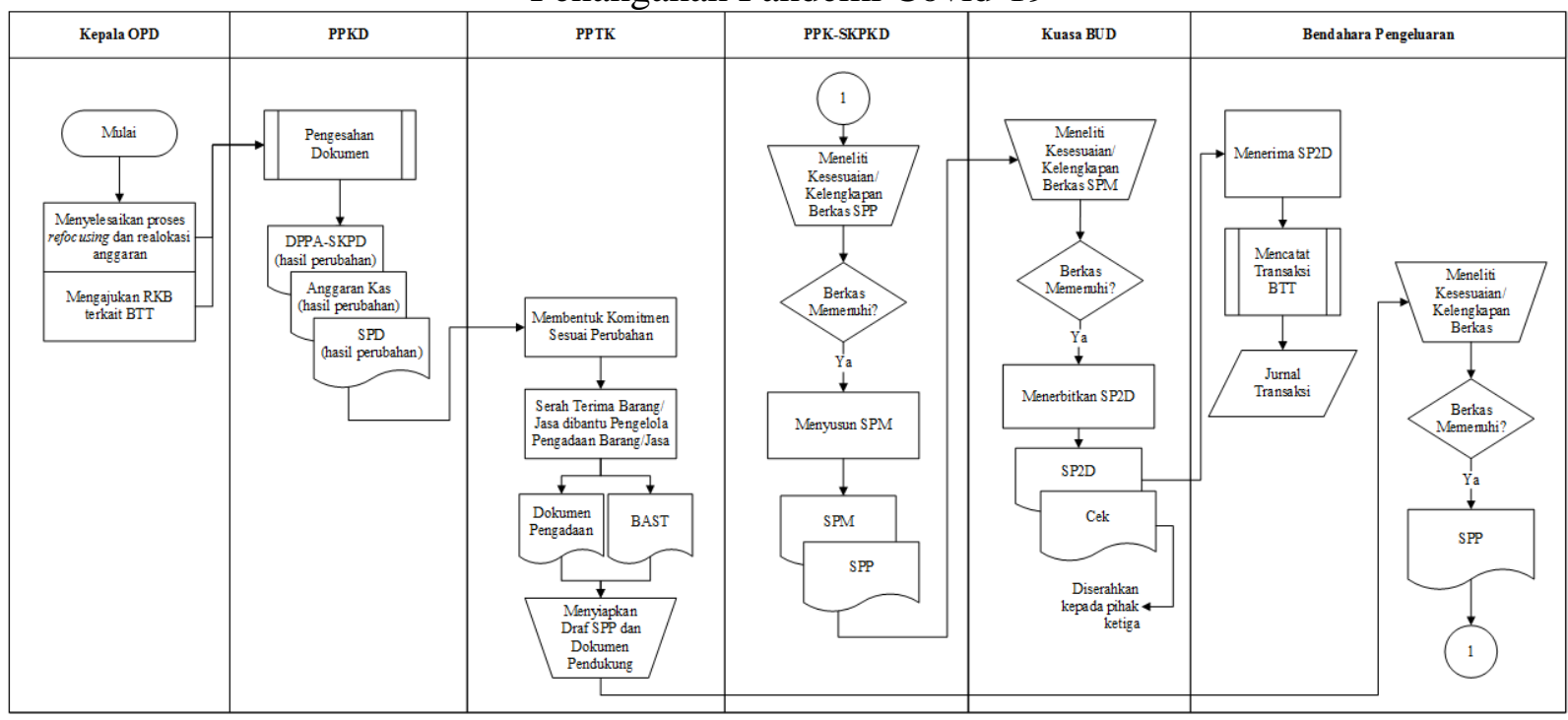

Sumber: diolah penulis

\section{Perbandingan Siklus Pelaksanaan Belanja Pemerintah Daerah Kabupaten “ABC” pada Masa Pandemi Covid-19}

Perbedaan siklus pelaksanaan belanja untuk keperluan non-penanganan pandemi Covid-19 dengan keperluan penanganan Covid-19 terdapat dalam tahap persiapan pelaksanaan anggaran. Hal ini dikarenakan perbedaan dasar yang digunakan dalam penyusunan setiap dokumen yang diperlukan. Dokumen terkait persiapan pelaksanaan belanja keperluan nonpenanganan pandemi Covid-19 berdasarkan pada ketentuan penganggaran sesuai dengan Perda APBD. Sementara itu, belanja keperluan penanganan Covid-19 didasarkan pada PAPBD yang di dalamnya berisi hasil refocusing dan realokasi yang telah dilakukan untuk percepatan pendanaan dalam penanganan Covid-19.

Dalam praktik penanggulangan pandemi Covid-19, meskipun penganggaran BTT terdapat pada PPKD yaitu Bakeuda "ABC" selaku BUD, pelaksanaan dan penatausahaan kegiatan dilaksanakan oleh OPD yang tergabung dalam gugus tugas percepatan penanganan Covid-19. Oleh karena itu, pengguna anggaran dalam transaksi BTT untuk keadaan darurat Covid-19 adalah OPD yang secara fungsional terkait dengan antisipasi dan penanganan dampak penularan Covid-19.

Selain itu, terdapat perbedaan waktu penyelesaian dokumen pencairan dana. Beberapa aktivitas pelaksanaan belanja dalam kondisi normal untuk keperluan non-penanganan Covid19 memiliki batas waktu penyelesaian relatif panjang/lama, sedangkan belanja keperluan penanganan pandemi Covid-19 diproses paling lama 1 (satu) hari dikarenakan adanya kebutuhan mendesak terhadap belanja pengadaan barang/jasa tersebut.

\section{PENUTUP}

\section{Simpulan}

Penanganan Covid-19 pada Pemerintah Daerah Kabupaten "ABC" ditandai dengan pembentukan gugus tugas percepatan penanganan Covid-19. Respon kebijakan keuangan terhadap Pandemi Covid-19 telah dilakukan Pemerintah Daerah Kabupaten "ABC" mengikuti ketentuan yang berlaku. Refocusing/realokasi anggaran telah dilakukan dengan menyisir anggaran dari kegiatan yang kurang diprioritaskan. Hasil refocusing/realokasi anggaran dituangkan dalam Perda P-APBD Tahun Anggaran 2020. Adapun rasionalisasi anggaran yang 


\section{JURNALKU}

Volume 1 No. 4, Desember 2021

dilakukan terhadap anggaran belanja telah tercermin dalam Perda P-APBD Tahun Anggaran 2020. Sementara itu, penggunaan BTT untuk penanganan Covid-19 dilaksanakan oleh OPD yang secara fungsional memiliki kewenangan terkait penanggulangan pandemi Covid-19.

Belanja daerah untuk keperluan penanggulangan Covid-19 pada Pemerintah Daerah Kabupaten "ABC" dianggarkan pada BTT yang kemudian dituangkan dalam P-APBD hasil dari refocusing dan/atau realokasi anggaran dan penyediaan dana melalui rasionalisasi anggaran. Penganggaran BTT dipusatkan pada SKPKD selaku BUD, sehingga pelaksanaan belanja keperluan Covid-19 pada Pemerintah Daerah Kabupaten "ABC" termasuk dalam belanja yang belum tersedia anggarannya. Adapun penatausahaan dan pelaksanaan BTT dilakukan oleh OPD yang memiliki keterkaitan dengan antisipasi dan penanganan dampak penularan Covid-19 secara fungsional sebagai pengguna anggaran.

Siklus pelaksanaan anggaran belanja untuk keperluan penanganan pandemi Covid-19 pada Pemerintah Daerah Kabupaten "ABC" dimulai dengan tahap persiapan pelaksanaan APBD yang terdiri atas aktivitas penyesuaian DPA, penyesuaian anggaran kas, dan penyesuaian SPD. Sementara itu, tahap pelaksanaan belanja APBD terdiri atas aktivitas pembuatan komitmen berdasarkan hasil perubahan anggaran, serah terima barang/jasa, pengajuan dokumen SPP, pengajuan dokumen SPM, dan pencairan dana melalui penerbitan SP2D. Kebutuhan yang sifatnya mendesak menyebabkan pemrosesan dokumen pencairan dana belanja keperluan penanganan pandemi Covid-19 yang lebih cepat, dimana waktu penyelesaian menjadi paling lama 1 (satu) hari.

Meskipun tidak berbeda secara signifikan, kebijakan keuangan (termasuk di dalamnya pola penganggaran BTT) berdampak pada beberapa aktivitas beserta data masukan/keluaran dalam siklus pelaksanaan anggaran belanja penanganan pandemi Covid-19, dibandingkan dalam kondisi normal atau untuk belanja non penanganan Covid-19. Aktivitas dalam siklus pelaksanaan belanja didasarkan pada hasil penyesuaian anggaran.

\section{Keterbatasan dan Rekomendasi}

Fokus penulisan jurnal ini adalah kebijakan keuangan dan dampaknya terhadap siklus pelaksanaan anggaran belanja pada masa pandemi Covid-19 terutama untuk belanja dengan mekanisme pembayaran LS. Detail pelaksanaan kegiatan masing-masing bidang perlu kajian tersendiri. Pengendalian terhadap aktivitas siklus pelaksanaan belanja tersebut juga belum dieksplorasi. Sehingga, masih tersedia ruang untuk mengkaji lebih detail masing-masing bidang dalam penanganan kondisi mendesak/darurat dan aspek pengendalian dalam siklus tersebut.

\section{DAFTAR PUSTAKA}

Agnika, M., Putra, S. S., \& Sudradjat. (2021). Analisis Kinerja Anggaran Pendapatan dan Belanja Daerah pada Pemerintah Daerah Kabupaten Subang Sebelum dan Saat Pandemi Covid-19. Indonesian Accounting Research Journal, 1(3), 493-503. Retrieved from https://jurnal.polban.ac.id/ojs-3.1.2/iarj/article/view/3040/2361

Badan Pusat Statistik Kabupaten "ABC”. (2021). Kabupaten "ABC” dalam Angka 2021. BPS Kabupaten "ABC".

Basri, Y., \& Gusnardi, G. (2021). Pengelolaan Keuangan Pemerintah di Masa Pandemi Covid19 (Kasus Pada Pemerintah Provinsi Riau). Jati: Jurnal Akuntansi Terapan Indonesia, 4(1), 33-48.

Joyce, P. G., \& Prabowo, A. S. (2020). Government responses to the coronavirus in the United States: immediate remedial actions, rising debt levels and budgetary hangovers. Journal of Public Budgeting, Accounting \& Financial Management, ISSN 1096-3367, 32(5), 745-758. https://www.emerald.com/insight/content/doi/10.1108/JPBAFM-07$\underline{2020-0111 / \text { full/html }}$ 


\section{JURNALKU}

Volume 1 No. 4, Desember 2021

Kabupaten “ABC”. (2014). Peraturan Daerah Kabupaten "ABC” Nomor 3 Tahun 2014 tentang Pokok-Pokok Pengelolaan Keuangan Daerah.

Kabupaten "ABC". (2019). Peraturan Daerah Kabupaten "ABC" Nomor 12 Tahun 2019 tentang Anggaran Pendapatan dan Belanja Daerah Tahun Anggaran 2020.

Kabupaten "ABC”. (2020). Keputusan Bupati “ABC” No. 188.45/207/406/001/3/2020 tentang Gugus Tugas Percepatan Penanganan Corona Virus Disease 2019 (Covid-19).

Kabupaten "ABC". (2020). Peraturan Daerah Kabupaten "ABC" Nomor 10 Tahun 2020 tentang Perubahan Anggaran Pendapatan dan Belanja Daerah Tahun Anggaran 2020.

Kementerian Dalam Negeri. (2020). Instruksi Menteri Dalam Negeri Nomor 1 Tahun 2020 tentang Pencegahan Penyebaran dan Percepatan Penanganan Corona Virus Disease 2019 di Lingkungan Pemerintah Daerah.

Kementerian Dalam Negeri (2020). Peraturan Menteri Dalam Negeri Nomor 20 Tahun 2020 tentang Percepatan Penanganan Corona Virus Disease 2019 di Lingkungan Pemerintah Daerah.

Kim, B. H. (2020). Budgetary responses to COVID-19: the case of South Korea. Journal of Public Budgeting, Accounting \& Financial Management, ISSN 1096-3367, 32(5), 939-947. https://www.emerald.com/insight/content/doi/10.1108/JPBAFM-06-20200079/full/html

Matthew B., A., Huberman, M., \& Miles, J. S. (2014). Qualitative data analysis: a methods sourcebook (Third Edit). SAGE Publications, USA

Mulyana, B. (2014). Buku Seri Akuntansi Pemerintah: Akuntansi Pemerintah Daerah (Buku 3). Tangerang Selatan: Sekolah Tinggi Akuntansi Negara.

Mulyana, B. \& Sugiri, D. (2020). Pengelolaan Keuangan Daerah: Cara Mudah Memahami Pengelolaan Keuangan Daerah sesuai Peraturan Terbaru. Tangerang Selatan: Politeknik Keuangan Negara STAN.

Republik Indonesia. (2020). Peraturan Pemerintah Pengganti Undang-Undang (Perpu) tentang Kebijakan Keuangan Negara dan Stabilitas Sistem Keuangan untuk Penanganan Pandemi Corona Virus Disease 2019 (COVID-19) dan/atau dalam Rangka Menghadapi Ancaman yang Membahayakan Perekonomian Nasional dan/atau Stabilitas Sistem Keuangan.

Republik Indonesia. (2019). Peraturan Pemerintah No. 12 Tahun 2019 tentang Pengelolaan Keuangan Daerah.

Republik Indonesia. (2020). Keputusan Presiden Nomor 12 Tahun 2020 tentang Penetapan Bencana Nonalam Penyebaran Corona Virus Disease 2019 (Covid-19) sebagai Bencana Nasional.

Republik Indonesia (2020). Surat Keputusan Bersama Menteri Dalam Negeri dan Menteri Keuangan Nomor 119/2813/SJ; Nomor 177/KMK.07/2020 tentang Percepatan Penyusunan Anggaran Pendapatan dan Belanja Daerah Tahun 2020 dalam Rangka Penanganan Corona Virus Disease 2019 (Covid-19) serta Pengamanan Daya Beli Masyarakat dan Perekonomian Nasional.

Sanjaya, N. (2020). Kebijakan Penganggaran Daerah Dimasa Pandemi Covid-19 (Study Kasus pada Pemerintah Daerah Provinsi Banten. Jurnal Ilmu Administrasi, 17(2), 273-290. http://jia.stialanbandung.ac.id/index.php/jia/ article/view/608/pdf

Schiavo-Campo, S. (2017). Government Budgeting and Expenditure Management, Principles and International Practice. New York: Routledge.

Sugiri, D. (2021). Perlakuan Akuntansi Belanja Tak Terduga pada Pemerintah Daerah Akibat Pandemi Covid-19. Jurnal Ilmiah Akuntansi dan Keuangan, 10(1), 56-58. https://doi.org/10.32639/jiak.v10i1.599 


\section{JURNALKU}

Volume 1 No. 4, Desember 2021

Susanto, V. Y. (2021). BPK: Pengelolaan Dana Penanganan Covid-19 di Daerah Bermasalah https://insight.kontan.co.id/news/bpk-pengelolaan-dana-penanganan-covid-19-didaerah-bermasalah-1/amp (diakses pada 27 November 2021)

Tim Kerja Kementerian Dalam Negeri untuk Dukungan Gugus Tugas COVID-19. (2020). Pedoman Umum Menghadapi Pandemi Covid-19 bagi Pemerintah Daerah: Pencegahan, Pengendalian, Diagnosis dan Manajemen. Kementerian Dalam Negeri 